\title{
"Fiscal interest of the state and respecting the rights and legitimate interests of the taxable entities in case of refund of excess remission of value added tax"
}

\author{
Ol'ga Kmetová \\ AUTHORS Magdaléna Freňáková \\ Miloš Pachta (D https://orcid.org/0000-0003-1861-1419
}

Ol'ga Kmetová, Magdaléna Freňáková and Miloš Pachta (2017). Fiscal interest of the state and respecting the rights and legitimate interests of the taxable entities

ARTICLE INFO in case of refund of excess remission of value added tax. Investment Management and Financial Innovations, 14(2-1), 207-217.

doi:10.21511/imfi.14(2-1).2017.06

DOI

http://dx.doi.org/10.21511/imfi.14(2-1).2017.06

RELEASED ON

Monday, 17 July 2017

RECEIVED ON

Wednesday, 11 January 2017

ACCEPTED ON

Tuesday, 28 March 2017

\section{(cc) EY-No}

LICENSE

This work is licensed under a Creative Commons Attribution-NonCommercial 4.0 International License

JOURNAL

"Investment Management and Financial Innovations"

ISSN PRINT

$1810-4967$

ISSN ONLINE

$1812-9358$

PUBLISHER

LLC "Consulting Publishing Company "Business Perspectives"

FOUNDER

LLC "Consulting Publishing Company "Business Perspectives"

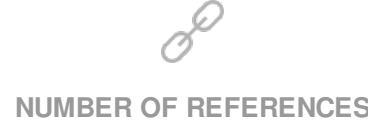

20
NUMBER OF FIGURES

1
靖

NUMBER OF TABLES

0

(C) The author(s) 2022. This publication is an open access article. 


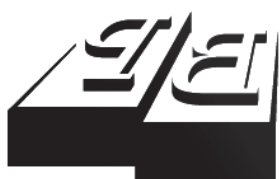

BUSINESS PERSPECTIVES

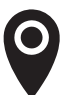

LLC “CPC "Business Perspectives" Hryhorii Skovoroda lane, 10, Sumy, 40022, Ukraine

www.businessperspectives.org

Received on: $11^{\text {th }}$ of January, 2017 Accepted on: $28^{\text {th }}$ of March, 2017

(c) Ol'ga Kmetová, Magdaléna Freňáková, Miloš Pachta, 2017

Ol'ga Kmetová, JUDr., CSc., Department of Financial Management, Faculty of Business Economics with seat in Košice, University of Economics in Bratislava Slovak Republic.

Magdaléna Freňáková, Ing., PhD., Department of Financial Management, Faculty of Business Economics with seat in Košice, University of Economics in Bratislava, Slovak Republic.

Miloš Pachta, Ing., Faculty of Business Economics with seat in Košice, University of Economics in Bratislava, Slovak Republic.

\section{(ㄷ)(1) $(8)$}

This is an Open Access article, distributed under the terms of the Creative Commons Attribution-NonCommercial 4.0 International license, which permits re-use, distribution, and reproduction, provided the materials aren't used for commercial purposes and the original work is properly cited.
Olga Kmetová (Slovak Republic), Magdaléna Freňáková (Slovak Republic), Miloš Pachta (Slovak Republic)

\section{FISCAL INTEREST OF THE STATE} AND RESPECTING THE RIGHTS AND LEGITIMATE INTERESTS OF THE TAXABLE ENTITIES IN CASE OF REFUND OF EXCESS REMISSION OF VALUE ADDED TAX

\begin{abstract}
The authors of this article, based on the principle of legitimacy, state that tax authorities in tax proceedings protect not only the fiscal interests of the state as a priority, but at the same time they are obliged to maintain the rights and legitimate interests of the taxable entities, analyze the current legislation of the tax audit in aspect of permissible statutory length of its duration and its impact on the process of refund of excess remission of VAT to the taxable entities.
\end{abstract}

\section{Keywords tax audit, length of tax audit, refund of excess remission of VAT}

\section{JEL Classification $\quad \mathrm{M} 41, \mathrm{M} 42, \mathrm{H} 25$}

\section{INTRODUCTION}

Taxes are obligatory and non-refundable payments collected by the state represented by financial authorities under the Act. The basic function of taxes is a fiscal function, which monitors the revenue from taxes as income components of the state budget, with the fact that this revenue will be used to cover government and other public needs. The tax obligation arises from the law or under a law by decision of the tax office.

Tax administration, in view of its purpose in relation to the fiscal interests of the state, is adjusted by the appropriate substantive and procedural rules of public law so that the taxable entity is, among other things, obliged to calculate tax obligation, admit it and also furnish it through proper accounting and other documentary evidence, while in the context of tax proceedings, taxable entity carries the burden of proof. This applies fully to the application of excess remission of value added tax (VAT).

As these are the fiscal interests of the state, Tax Procedure Code1 contains specific regulation of ascertaining and examining of the tax base

1 Act No. 563/2009 Coll. on Tax Administration (Tax Procedure Code) and on Amendments and Supplements to Certain Acts. 
or other facts for the correct determination of tax or formation of a tax liability of the taxable entity. The tax administrator shall be entitled and as well obliged using institute of tax audit and other procedural procedures, course at respecting procedural rights of taxable entities, to ascertain and to verify the tax base or other facts for the correct determination of tax or claim for refund of VAT.

The scheme of procedure in order to prove rightfulness of a claim for refund of remission of VAT according to the provision of Article 49(2) of Act No. 222/2004 Coll. on Value Added Tax ${ }^{2}$ (hereinafter referred to as "Act on VAT") is a special provision in relation to the way of proving according to Tax Procedure Code. The provisions of Article 49(2) and Article 51 of Act on VAT determine how the taxpayer is required to prove rightfulness of a claim for refund of remission of VAT, since what date the entitlement arose and how the taxable performance shall be used in order to be entitled to claim for refund of remission of VAT.

According to one of basic principles of Tax Proceedings - principle of legitimacy - tax administration shall be carried out by a tax administrator according to the generally binding legal regulations, while protecting interests of the state and municipalities and respecting the rights and legitimate interests of taxable entities and other persons participating in tax proceedings.

The principle of legitimacy of tax proceedings results from constitutional principle of legitimacy of taxation, which is expressed in Article 59(2) of Constitution of the Slovak Republic. From diction of cited provision results, the tax authorities in tax proceedings can not protect only fiscal interests of the state as a priority, but, at the same time, they have obligation to respect the rights and legitimate interests of taxable entities. It means that the principle of legitimacy of tax proceedings is an important guarantee of legal security for taxable entities.

The fact that tax authorities have obligation to respect the rights and legitimate interests of taxable entities and other persons is not in conflict with their duty to protect the interests of the state.

Although in relation to respecting the rights and legitimate interests of taxable entities is the interest of the state superior, it can not be in the meaning that tax revenues as incomes of state budget reached at the expense of non-compliance with law. Tax authorities may apply, in case of assessing tax, only legal means, which are prescribed by law or which tax authorities are authorized to apply according to its authorization resulting from law.

In regard to such legal fact as refund of excess remission of VAT, the question of permissible statutory (legal) length of the tax audit duration arises and the related question of wrongful retention of excess remission of VAT in the detriment of taxable entities arises at present.

The article pays attention to analyzing the current legislation of the tax audit from the aspect of permissible statutory length of its duration and its impact on the process of refund of excess remission of VAT to taxable entities.

2 Act No. 222/2004 Coll. on Value Added Tax as amended by Certain Acts. 
1. TAX AUDIT IN THE CONTEXT OF PERMISSIBLE STATUTORY LENGTH OF ITS DURATION IN THE SLOVAK REPUBLIC

\subsection{Some notes to history of the tax audit legislation from the perspective of permissible statutory length of its duration}

The tax audit is an important part of the content of public financial activity and is also a significant means of tax administration. In general, by means of tax audit, a tax administrator shall find out or verify the facts decisive for the correct determination of $\operatorname{tax}^{3}$.

For the tax audit, it is characteristic that during the tax audit, there is such an immediate and long-term contact between the tax administrator and controlled taxable entity than in any other procedural act. During the tax audit, each of the parties protects and asserts its own interests. The tax administrator protects the fiscal interests of the state and municipalities and on the side of the taxable entities, there is an attempt to minimize own tax burden, of course, in accordance with the law. Moreover, during this tax and as well legal contact between the tax administrator and controlled taxable entity during the tax audit, the tax administrator has a superior position. All this necessarily leads to the need for regulation of mutual rights and obligations of these entities, but, above all, to the need for regulation of procedure of tax administrator during the tax audit (Babčák, 2015). The duration of the tax audit in terms of the importance of its consequences is limited by statutory regulation, as it is also in case of other types of procedural procedures of the tax administrator. Respecting of the legal time limits determined by Tax Procedure Code has a significant impact on the assessment of the legality of performed tax audit.
The illegality of tax audit is determined by breach of legal provisions related to the time limits for the performance of tax audit. Any tax audit, even if it is performed on the basis of legal empowerment within the legal powers of the tax administrator, is an invasion of individual autonomous sphere of the audited entity. In this legitimate intervention, the tax administrator should not interfere into the sphere of private autonomy of tax entity over his authorization stipulated by law what reflects the constitutional imperative to act only to the extent and in a manner which shall be laid down by law ${ }^{4}$.

In the development of legislation of legal regulation of tax audit length, we observed a significant shift in favor of the rights of taxable entity. Act No. 511/1992 Coll. ${ }^{5}$ originally did not prescribe any time limit for the performance of tax audit, respectively, for completion of tax audit. The fact decisive for the assessment of legal borders of permissibility and eligibility of tax audit has been its performance in the scope inevitably required to attain the purpose according to this $\mathrm{Act}^{6}$.

Response to numerous cases of long lasting tax audits, increasing mainly late 90's and at the beginning of this century (Vernarský, 2012) was the change of legislation ${ }^{7}$, according to which with effectiveness since 1 May 2003, the performance of the tax audit was limited by period of six months from the date of its commencement. In complicated cases, legislation admitted that the direct superior authority to the tax administrator shall appropriate by extend the time limit of six months before its expiration up to next six month.

From the judgment practice of tax administrators from this period, it is clear, however, that the time limit prescribed by law limited length of tax audit duration was considered as the indicative time limit with the breach of which is not associated with any underlying legal consequences (Vernarský, 2012). Thanks to the evolving case law of the Supreme Court of the Slovak Republic began to fore the need to respect the time limit of tax audit, respectively, limits for its necessary, but also

\footnotetext{
Article 44 of Act No. 563/2009 Coll. on Tax Administration (Tax Procedure Code) and on Amendments and Supplements to Certain Acts. Article 2(2) of Constitution of the Slovak Republic.

Act No. 511/1992 Coll. on Administration of Taxes and Fees and on Changes in the System of Regional Financial Authorities, as amended. Article 15(1) of Act No. 511/1992 Coll.

Act No. 114/2003 Coll., which amends and supplements Act No. 511/1992 Coll. on Administration of Taxes and Fees and on Changes in the System of Regional Financial Authorities.
} 
proper and maximum allowed performance. The Supreme Court of the Slovak Republic in its case law stated that the tax audit can not take place at the taxable entity during the unlimited time. In this regard, he stated that tax audit is an interference of a public authority info private and legal sphere of the entity, so it can be enforced only to the extent and in the manner prescribed by law. Any interference by a public authority in to the private and legal sphere of legal entity is governed by the universal principle of proportionality, and establishing deadlines for the tax audit is a manifestation of the principle of proportionality ${ }^{8}$. The issue of impact of tax audit length on the legality of the protocol as evidence in tax proceedings also addressed the Constitutional Court of the Slovak Republic, which upheld its legal interpretation of the case law of the Supreme Court of the Slovak Republic in the matter of the need to respect the legal time limit for the performance of a tax audit.

As the Constitutional Court of the Slovak Republic stated the time limit, which was established in Article 30a(7) of Act No. 511/1992 Coll. on Administration of Taxes and Fees and on Changes in the System of Regional Financial Authorities, is a statutory time limit and it is for the tax authority who performs a tax audit mandatory limit determining the legality of performed tax audit. The mentioned time limit can not be compared with the time limits for decision under Article 30a(1) through (4) of Act No. 511/1992 Coll. Tax audit as a process leading to the acquisition of evidence, which is not a meritorious process of deciding on the tax liability of the taxable entity, means a serious and intensive intervention into the individual sphere of the taxable entity, which is protected by law, from the side of the tax authority, which quite clearly results from the nature of the obligations of audited taxable entity during the tax audit (Article 15(6) of Act No. 511/1992 Coll.). The objective of tax audit can not be achieved at the expense of the rights and legitimate interests of taxable entities. Even in the tax proceedings, there is applied a principle of proportionality in case of interventions of the tax authority towards the taxable entity (Article 2(3) of Act No. 511/1992 Coll.). In some cases, the legislator has formulated this principle (requirement) quite precisely by specifying the limits of a particular type of intervention?.

At the same time, in another case, the Constitutional Court of the Slovak Republic examining the constitutionality of the decision of the Supreme Court of the Slovak Republic stated that "the state's interest in the implementation of the revenue side of the state budget is not and cannot be superior to the respect for and maintenance of the rights of taxpayers recognized by laws"

The Constitutional Court of the Czech Republic again held that in the field of public law (therefore, the tax law) the state authorities can only do what the law expressly permits (in contrast to the citizens who can do everything that is not prohibited). It follows then from this maxim that in the imposition and exaction of taxes according to the law, i.e., in the de facto confiscation of part of a person's property (Article 20 of the Constitution), public authorities are obliged to preserve the essence and purpose of fundamental rights and freedoms ${ }^{11}$.

\subsection{Duration of tax audit de lege lata}

The development of the tax audit legislation concerning the determination of maximum permissible length of its duration is stabilized in the current wording of provision of Article 46(10) of Tax Procedure Code and states that "the time limit for the performance of tax audit shall be no longer than one year since the date of commencement of the tax audit"12. In the case of tax audit of foreign dependent persons who determine tax base according to a special regulation, the second instance authority may extend the time limit before its expiry for a maximum of 12 months.

8 Ruling of the Supreme Court of the Slovak Republic in case Ref. No. 3 Sžf 73/2008. Judgment of the Supreme Court of the Slovak Republic in case Ref. No. 3 Sžf 107/2009.

9 Finding of the Constitutional Court of the Slovak Republic, Ref. No. III. ÚS 24/2010 of 29 June 2010

10 Finding of the Constitutional Court of the Slovak Republic, Ref. No. I. ÚS 241/07 of 18 September 2008.

11 Finding of the Constitutional Court of the Czech Republic, Ref. No. IV. ÚS 666/02. Finding of the Constitutional Court of the Slovak Republic, Ref. No. I. ÚS 241/07 of 18 September 2008.

12 Act No. 563/2009 Coll. on Tax Administration (Tax Procedure Code) effective since 1 January 2010, except Section I, which is effective since 1 January 2012. 
The opportunity of suspension of tax audit given by law has a significant impact on the duration of tax audit. The tax administrator may not arbitrarily suspend a tax audit, but only for reasons, which are exhaustively laid down by law. To any suspension of tax audit, a tax administrator shall apply accordingly Article 61 of Tax Procedure Code, according to which he shall suspend tax proceedings if it has any knowledge of the commencement of proceedings on a preliminary issue ${ }^{13}$. Also according to Article 61 of Tax Procedure Code, a tax administrator may optionally suspend tax proceedings if proceedings concerning another fact decisive for the issuance of a decision have been commenced or if information needs to be obtained in the way according to a special regulation ${ }^{14}$. The facts, which are legal reasons for obligatory or optional suspension of tax audit, are temporary obstacles for the performance of tax audit (Štrkolec, 2014). Whereas, during the suspension of tax audit according to Article 61(5) of Tax Procedure Code, the time limits according to this Act shall not lapse, shall not lapse the time limit for performance of tax audit, which shall be no longer than one year since the date of commencement of the tax audit. Institute of suspension of tax audit is capable of influencing to a significant extent negatively the actual length of tax audit for taxable entity.

\section{TAX AUDIT AND THE EXCESS REMISSION OF VAT}

Divergence of interests of the tax authority and the taxable entity during the performance of the tax audit is the most noticeable in situations, in which also for the taxable entity is decisive the fiscal interest. Especially significant are the manifestations of this interest in the case of the payer of value added tax who filing of tax return claim for refund of excess remission of VAT (Štrkolec, 2014). The interest of these taxable entities in the performance of the tax audit as soon as possible is evident, because the fiscal interest in the form of cash funds flowing from the refund of excess remission of VAT is usually decisive for the realization of their economic activities.

In principle, excess remission (deduction) of VAT shall be returned to taxable person within 30 days of the expiration of the time limit for the filing of a tax return for the taxation period in which the excess deduction was created, if:

1. the taxpayer's taxation period is a calendar month,

2. the taxpayer has been a taxpayer for at least 12 calendar months preceding the end of the calendar month in which the excess remission (deduction) was created, and

3. the taxpayer did not owe, for the period of 6 calendar months preceding the end of the calendar month in which the excess remission (deduction) was created, any tax arrears or customs arrears to the tax office or the customs office, or arrears arising from mandatory social insurance contributions pursuant to separate regulations more than EUR 1,000 in aggregate.

The refund of excess remission shall be a timeconsuming process, if the tax audit is being performed. According to amended Act No. 222/2004 Coll. on Value Added Tax, Article 79(6), if within the time limit for refunding the excess remission (deduction) the tax office initiates a tax audit, the tax office shall refund the excess remission (deduction) within ten days of the completion of the tax audit in the amount determined by the tax office. The tax office performs the tax audit according Article 46(2) of Tax Procedure Code; it is the tax audit in order to ascertain rightfulness of a claim for refund of excess remission.

In the case of commencement of tax audit the time limit for refunding the excess remission of VAT may be extended up to 12 months (with the possibility of its extension for a further 12 months in case of foreign taxable persons). Retention of funds to the taxable person corresponding to the excess remission of VAT may therefore be 12 to 24

13 For example, the inheritance proceeding takes place in court, a court negotiates procedural capacity of taxable entity to enter into legal transaction.

14 Council Regulation (EU) No. 904/2010 on administrative cooperation and combating fraud in the field of value added tax, Act No. 442/2012 Coll. on international assistance and cooperation in tax administration. 
Source: own processing on the basis of the data published by the Financial Directorate of the Slovak Republic.

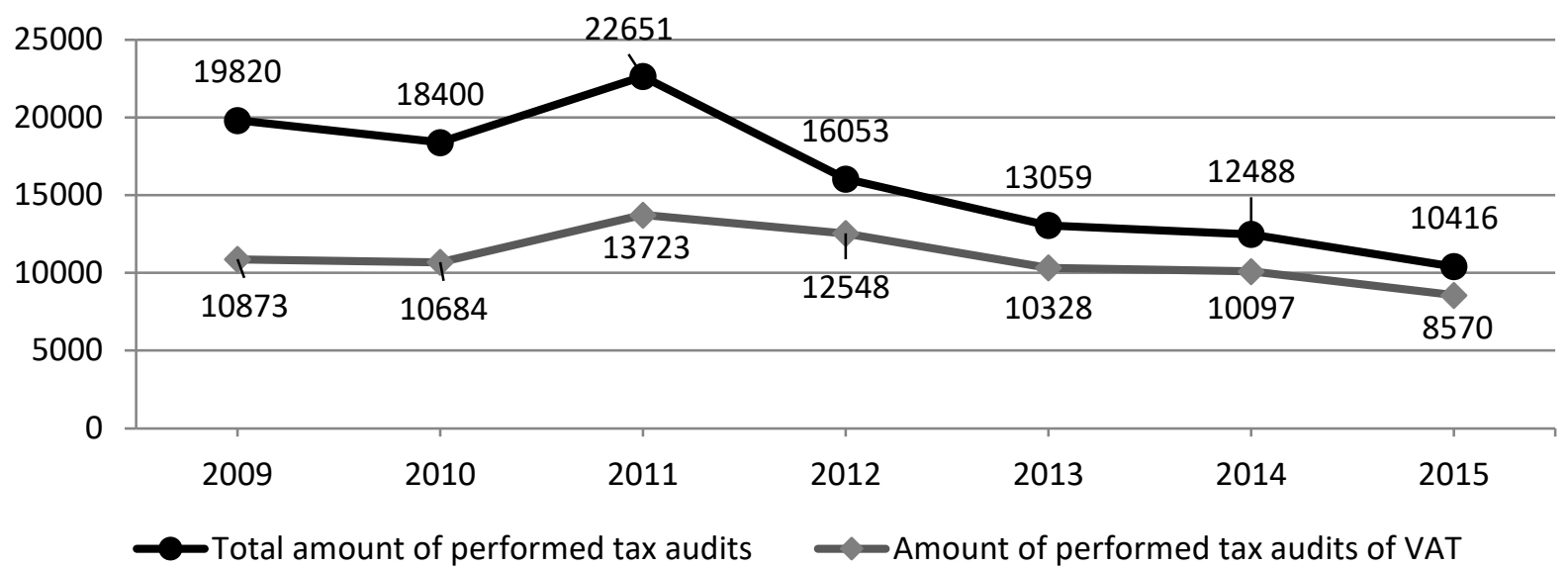

Figure 1. Number of tax audits performed in the period 2009-2015

times longer than the one month taxation period. This length of the tax audit duration is in our opinion inadequate and as well capable to paralyze the economic (business) activity of the taxable entity. Tax audit lasts a long time; finally it is shown that a claim for refund of excess remission was authoi rized (rightful) and that the excess remission was detained unreasonably for a long time.

The tax audit performed in order to ascertain rightfulness of a claim for refund of excess remission shall commence on the date when the minutes of commencement of the tax audit were drawn up or on the date stated in the notification of tax audit. In this context, it is important to give attention to the Article 46(9) of Tax Procedure Code regulating the completion of a tax audit. The tax audit performed in order to ascertain rightfulness of a claim for refund of excess remission according to Article 46(9)(a) of Tax Procedure Code shall be considered completed on the date of delivery of the protocol, which shall contain the outcome of the tax audit, including the evaluation of evidence or according to Article 46(9)(c) of Tax Procedure Code shall be considered completed on the date of cessation of the claim for refund of excess remission according to a special regulation. In reference to mentioned special regulation, the Tax Procedure Code refers to Article 79(6) of Act on VAT. Under the amended Article 79(6) of Act on
VAT with effectiveness since 1 January 2016, the preclusive time limit for refund of excess remission is reduced from 6 months to 3 months in case if a taxpayer does not enable the performance of the tax audit ${ }^{15}$. Consequence of not allowing the implementation of a tax audit in this case is "failure to return" excess remission (deduction) of VAT to taxable entity, as a strong expression of the sanction of the tax administrator in relation to the taxable entity due to lack of his cooperation.

\section{LENGTH OF TAX AUDIT AND EXCESS REMISSION OF VAT IN CONTEXT OF ACTUAL CASE LAW OF THE COURT OF JUSTICE OF THE EUROPEAN UNION}

Institute of tax audit suspension raises many questions about its legitimacy, especially in relation to the fact that up to $23 \%$ of tax audits duration exceeds one year (according to the fact of 31 December 2015), while the majority of these audits concern the VAT, as evidenced by the Figure 1.

The procedures by which the tax administrator applies the institute of tax audit suspension are often

15 If a taxpayer does not enable the performance of the tax audit within three months of its commencement date, the entitlement to a refund of the excessive remission (deduction) expires on the last day of the third month in the amount claimed in the tax return or additional tax return. 
based on the objective need for an international exchange of information for the correct determination of tax, but, on the other hand, the institute of tax audit suspension in practice may be subject to abuse. An example of this abuse can be a situation in which tax authority requests to provide such kind of information, which is irrelevant and not related to the subject of tax audit or there may be information that has previously been identified and reviewed and which therefore does not provide new facts.

Put into effect since 1 January 2016, Tax Procedure Code in Article 79 implements an obligation of the tax administrator to award interest to the taxable entity for every day in default, and this also in case if the tax administrator refunds the tax overpayment after the specified time limit according to Act on VAT. Interest on late payment shall be awarded to the taxpayer of VAT in all cases in which the time limit for refund of excess remission has not been met.

The taxpayer shall be entitled to interest on late payment if excess remission (deduction) is not refunded within the statutory time limit of 30 days, possibly 10 days for refund of excess remission. Slovak legislation provides that the interest on late payment shall be calculated for every day in default since the date of expiry of the time limit for refund of excess remission until the date of its payment. In the case of performing the tax audit in order to ascertain rightfulness of a claim for refund of excess remission of VAT, it means that the taxpayer shall be entitled to interest on late payment, if the tax administrator does not make a refund of excess remission awarded by the tax audit within the time limit of 10 days after the completion of tax audit in the amount determined by the tax office.

At present, case of certain compensation to the taxable entity for the period of retention of excess remission in case of positive result of tax audit in favor of the taxable entity is not regulated by the Slovak legislation.

According to the Article 183(1) of Council Directive 2006/112/EC of 28 November 2006 on the common system of value added tax hereinafter referred to as "Directive"): "Where, for a given tax period, the amount of deductions exceeds the amount of VAT due, the Member States may, in accordance with conditions which they shall determine, either make a refund or carry the excess forward to the following period".

According to several judgments of the Court of Justice of the EU, Article 183(1) of the Directive must be interpreted as precluding national legislation, which does not grant interest on temporary restriction disposition of funds from nonrefunded remission of VAT and later in text of this article we fully justified the conclusions of the European Court of Justice concerning the national legislation in the Slovak Republic, which prescribes that interests on late payment in case of refund of excess remission of VAT shall be calculated only as from 10 days after completion of the tax audit, what is contrary to Article 183(1) of the Directive.

a) The judgment of the Court of Justice of the EU in joined cases C-286/94, C-340/95, C-401/95 and C-47/96 dated 18 December 1997 (Garage Molenheide and others) analyzed among others also the question of remuneration of state detained excess remission during period of retention and the Court of Justice considered national legislation as incompatible with the principle of proportionality (see, to that effect, Molenheide and others, paragraphs 62).

b) The judgment of the Court of Justice of the EU in case C-25/07 dated 10 July 2008 (Alicja Sosnowska) especially in paragraph 17 , the Court stated that although "member states have a certain freedom to manoeuvre in determining the conditions for the refund of excess remission of VAT, those conditions cannot undermine the principle of neutrality of the VAT tax system by making the taxable person bear the burden of the VAT in whole or in part. In particular, such conditions must enable the taxable person, in appropriate circumstances, to recover the entirety of the credit arising from that excess VAT. This implies that the refund is made within a reasonable period of time by a payment in liquid funds or equivalent means, and that, in any event, the method of refund adopted must not entail any financial risk for the taxable person". 
c) A question of compatibility of national legislation with the VAT Directive was solved in the judgment of the Court of Justice of the EU dated 12 May 2011 in case C-107/10 (Enel Maritsa Iztok), according to which tax audit commenced according to the national legislation suspended period for refund of excess remission of VAT. The Court consistently stated in the judgments mentioned above, as well as in this judgment in paragraph 33 that "...the refund is made within a reasonable period of time by a payment in liquid funds or equivalent means, and that, in any event, the method of refund adopted must not entail any financial risk for the taxable person".

In the paragraph 51 of the judgment of the Court of Justice of the EU in case C-107/10 (Enel Maritsa Iztok): “...it has been consistent$l y$ held by the Court that calculation of the interest payable by the Treasury which does not take as its starting point the date on which the excess VAT would have had to be repaid in the normal course of events in accordance with the VAT Directive would be contrary, in principle, to the requirements of Article 183 of that directive (see, to that effect, Molenheide and Others, paragraphs 63 and 64)".

In the paragraph 53 of the judgment of the Court of Justice of the EU in case C-107/10: "It follows that the period for refunding excess VAT may, as a general rule, be extended in order to carry out a tax investigation without there being any need for such an extended period to be regarded as unreasonable provided that the extension does not go beyond what is necessary for the successful completion of the investigation (see, by analogy, Sosnowska, paragraph 27). However, in so far as the taxable person is deprived on a temporary basis of funds corresponding to the excess VAT, he is at an economic disadvantage which can be compensated for by payment of interest, thus ensuring compliance with the principle of fiscal neutrality".

In the paragraph 57 of the judgment of the Court of Justice of the EU in case C-107/10: "Therefore, the taxable person may not only suf- fer financial disadvantages but is also unable to predict the date from which funds corresponding to the excess VAT will be made available to him, thus entailing an additional burden for that person".

On the question of the indirect effect of the Directive we stress that in case of failure of proper and timely transposition of the Directive into national law it is appropriate to confer legal effect of the Directive directly in proceedings before national courts. In principle, we distinguish between two types of action, respectively application of the Directive, the direct effect which gives to an entity specific rights and obligations and the indirect effect which gives to an entity a possibility to require that the Court will apply in a particular case so-called euroconformal interpretation of national law in accordance with the provisions and objectives of Directive. Participant of the tax, as well as legal proceedings may legitimately ask to take into account the indirect effect of Directives, e.g., that national law is interpreted euroconformally ${ }^{16}$. The euroconformal interpretation requires when assessing entitlement to interests on late refunded excess remission of VAT that the interests should be in full based on the case law of the Court of Justice of the EU, what is interpreted by the relevant provisions of Directive 2006/112/EC.

A significant shift in favor of taxable entities, as regards the issue of a time limit of tax audit in relation to the refund of excess remission to the taxable entity, in our opinion, represents the actual resolution of the Court of Justice of the EU C-120/15 dated 21 October 2015 in case Kovozber, Ltd. contra the tax office Košice, which is based on the following facts and legal conclusions referred to below.

Due to the ongoing national disputes concerning the award of interest on late payment for the period from 31 days after the time limit for filing the tax return of value added tax for the relevant tax period till the refund of excess remission the Regional Court in Košice submitted a reference for a preliminary ruling in proceedings under Ref. No. 7 S 21/2012 concerns the interpretation of Article 183, paragraph 1 of the Directive. By a preliminary

16 For example the Judgments of the Court of Justice of the EU in cases C-14/83 (Sabine von Colson and Elisabeth Kamann), C-397/01 (Bernhard Pfeiffer), C-212/04 (Konstantinos Adeneler and others). 
question the Regional Court in Kosice asked the European Court of Justice for a response whether Article 183(1) of Directive 2006/112/EC amended by Directive 2006/138/EC shall be interpreted as precluding national legislation which prescribing that default interest (interest on late payment) relating to the refund of excess VAT is to be calculated only as from 10 days after completion of a tax audit performed in order to ascertain rightfulness of a claim for refund of excess remission.

About this preliminary question the Court of Justice of the EU decided by Order of the Court (Ninth Chamber) dated 21 October 2015 (Case C-120/15). In this proceeding, the Court emphasized that Article 183 of the VAT Directive does not lay down any obligation to pay interest on a refund of excess remission of VAT or the date from which such interest is payable. However, it can not be concluded from that fact alone that is provision must be interpreted as meaning that no control may be exercised under European Union law over the procedures established by Member States for the refund of excess remission of VAT. The principle of fiscal neutrality is interpreted by the Court so that conditions must enable the taxable person, in appropriate circumstances, to recover the entirety of the credit arising from that excess remission of VAT and this implies that the refund is made within a reasonable period of time by a payment in liquid funds or equivalent means, and the method of refund adopted must not entail, in any event, any financial risk for the taxable person.

On the other hand, the Court acknowledges that the Member States are required to check the tax returns of taxable persons, their financial statements and other relevant documents in order to proper collection of VAT due and that is why the period for refunding excess remission of VAT may, as a general rule, be extended in order to carry out a tax audit without there being any need for such an extended period to be regarded as unreasonable provided that the extension does not go beyond what is necessary for the successful completion of the tax audit. A considerable extension of the time limit for refund of excess remission exposes a taxable person to financial disadvantage and, moreover, the taxable person can not predict the date from which may dispose of the funds in the amount of excess remission. In this regard, the Court emphasizes that because the taxable person is deprived on a temporary basis of funds corresponding to the excess VAT, he is at an economic disadvantage, which can be compensated for by payment of interest. This ensures compliance with the principle of fiscal neutrality.

To this issue, the Court has declared that when a refund of excess remission of VAT is made to the taxable person after the expiry of reasonable time limit, the principle of fiscal neutrality of tax system requires that thus generated financial losses to the detriment of taxable person resulting from inability to dispose of the funds in question shall be compensated for by payment of default interests.

It follows that the taxable persons to whom the refund of excess remission (deduction) was made after the completion of the tax audit, the length of which exceeded a reasonable time limit, are entitled to the payment of default interests under European Union law. The calculation of the interests must take into consideration as its starting point the date on which the excess remission would have had to be repaid in the normal course of events in accordance with the VAT Directive. To the issue of application of interest on late payment the Court held that in case of the absence of European Union legislation it is for the domestic legal system of each member state to determine the conditions under which they have to pay interests on late payment. However, these conditions must observe the principles of equivalence and effectiveness, and therefore must not be less favorable than those to similar claims based on provisions of national law. At the same time they must not be framed so as to make impossible the exercise of rights admitted by the Union law or to excessively obstruct this exercise.

The Court in the order of preliminary question emphasizes that the Court is not competent to interpret national law or to apply Union rules in the particular cases. The Court holds that it is for the national court to determine whether, in the case which held, the principles of equivalence and effectiveness are adhered or ensure that they will be adhered. The national court is authorized to apply the provisions of European Union law and has the obligation to ensure their full effect. 
From the facts mentioned above and from the judgments of the Court follow that in case of refund of excess remission after the tax audit is completed:

- A taxpayer is entitled to compensation of financial loss, which resulting from the impossibility to dispose of financial amounts of excess remissions by paying interests on late payments.

- The calculation of interests must take into account as starting point the date on which the excess remission of VAT would have had to be refunded in the normal course of events in accordance with the VAT directive.

The provision of Article 79(3) of Tax Procedure Code contains the calculation of interests of the tax overpayment: "If the tax administrator refunds the tax overpayment after the time limit referred to in Article 79(2), it shall be obliged, within a time limit of 15 days after the refund of the tax overpayment, to decide on the award of interest on the amount of the tax overpayment if the amount of the tax overpayment exceeds EUR 5. A triple of the basic interest rate of the European Central Bank valid on the last date of the time limit within which the amount of the tax overpayment was supposed to be refunded according to this Act shall be used for the calculation of the interest; if the triple of the basic interest rate of the European Central Bank is lower than $10 \%$, the interest rate of $10 \%$ per annum shall be used for the calculation of interest instead of the triple of the basic interest rate of the European Central Bank. The interest shall be awarded for every day in default".

According to Article 79(7) of Tax Procedure Code the provisions of interest of the tax overpayment shall apply accordingly to interest in case of late refund of excess remission.

An algorithm of the calculation of interest is as follows:

$$
\begin{aligned}
& \text { Interest }=\frac{1}{365 \text { days }} \times \\
& \times \text { amount of the overpayment } \times \\
& \times \text { basic interest rate of the ECB } \times \\
& \times 3, \text { or } 10 \% \times \text { number of days, }
\end{aligned}
$$

where:

the basic interest rate of the European Central Bank - valid on the last date of the time limit within which the amount of the tax overpayment was supposed to be refunded;

365 days - depend on number of days of the calendar year.

The date when the amount of the overpayment was debited from the account of the tax administrator shall be considered as the date of refund of the overpayment.

\section{CONCLUSION}

An application practice of the tax audit in the context of refund of excess remission of VAT shows, that commencement of the tax audit and its subsequent performance are able to disproportionately extend the time limit for refunding excess remission of VAT and taxable entity is often at economic risks in the context of the conducting of its business. The decision of the Court of Justice of the EU has indicated a breakthrough, legally relevant and necessary approach of tax administrators on the issue of compensation for retention of funds in the amount of excess remission of VAT if the tax audit was initiated in order to ascertain rightfulness of a claim for refund of excess remission of VAT. In this context, we consider important to note that despite the current absence of national legislation it is necessary, also taking into account the decisions of the Court regarding the priority of application of European Union law, to respect the decision of the Court of Justice on a preliminary ruling in the matter of interest on late payment for wrongful retention of excess remission of VAT and to fully apply this decision in question in the national lawsuits and proceedings and as well in decision-making practices of the tax administrators. 
For the sake of objectivity, in conclusion, we consider it should be noted that at Meeting of the National Council of the Slovak Republic on 12 October 2016 there was approved an amendment to the Act of VAT and Tax Procedure Code, which with effectiveness from 1 January 2017 will regulate compensation for retention of excess remission of VAT during the tax audit. However, after being informed of its content ${ }^{17}$ (the amendment at the time of preparing this article has not yet been published in the Collection of Laws) we afford to express doubts whether the approved legislative regulation of this serious issue is compatible with European Union law and with above mentioned decisions of the Court Justice of the EU.

\section{REFERENCES}

1. Act No. 222/2004 Coll. on Value Added Tax as amended by Certain Acts.

2. Act No. 511/1992 Coll. on Administration of Taxes and Fees and on Changes in the System of Regional Financial Authorities, as amended.

3. Act No. 563/2009 Coll. on Tax Administration (Tax Procedure Code) and on Amendments and Supplements to Certain Acts.

4. Babčák, V. (2015). Daňové právo na Slovensku. Bratislava: EPOS, $752 \mathrm{~s}$.

5. Bonk, F. (2016). Fiškálny záujem štátu verzus dížka trvania daňovej kontroly. Zborník Dni práva 2015. Dohled, dozor, kontrola ve veřejné finanční činnosti. Brno : Masarykova univerzita.

6. Constitution of the Slovak Republic Act No. 460/1992 Coll. as amended by the constitutional Acts.

7. Council Directive 2006/112/ EC of 28 November 2006 on the common system of value added tax. Retrieved from http://eurlex.europa.eu/legal-content/EN/ $\mathrm{ALL} /$ ?uri=celex\%3A32006L0112
8. Finding of the Constitutional Court of the Slovak Republic, Ref. No. III. ÚS 24/2010 of 29 June 2010.

9. Finding of the Constitutional Court of the Slovak Republic, Ref. No. I. ÚS 241/07 of 18 September 2008.

10. Finding of the Constitutional Court of the Czech Republic, Ref. No. IV. ÚS 666/02.

11. Judgment of the Court (First Chamber) of 10 July 2008. Case C-25/07 (Alicja Sosnowska). Retrieved from http://eur-lex. europa.eu/legal-content/EN/TXT / qqid=1479688545759\&uri=CELE X:62007CJ0025

12. Judgment of the Court (Third Chamber) of 12 May 2011. Case C-107/10 (Enel Maritsa Iztok). Retrieved from http://eur-lex. europa.eu/legal-content/EN/ T/?uri=CELEX\%3A62010CJ0107

13. Judgment of the Supreme Court of the Slovak Republic in case Ref. No. 3 Sžf 107/2009.

14. Kubincová, S. (2015). Daňový poriadok: Komentár. Bratislava: C. H. Beck, 750 s.
15. Order of the Court (Ninth Chamber) of 21 October 2015. Case C-120/15 (Kovozber). Retrieved from http://curia.europa.eu/juris/liste. jsf language $=$ en $\&$ num $=C-120 / 15$

16. Ruling of the Supreme Court of the Slovak Republic in case Ref. No. 3 Sžf 73/2008.

17. Štrkolec, M. (2014). Prerušenie daňovej kontroly - prípustnost', dôsledky a možnosti procesnej obrany. Justičná revue, 66(11).

18. The explanatory memorandum to the government bill which amends Act No. 222/2004 Coll. on Value Added Tax and which amends Act No. 331/2011 Coll., which amends Act No. 563/2009 Coll. on Tax Administration (Tax Procedure Code) and on Amendments and Supplements to Certain Acts. Retrieved from https://www.nrsr. sk/web/Default.aspx?sid=zakony/ cpt\&ZakZborID=13\&CisObdobia $=7 \& \mathrm{ID}=183$

19. TREND. (2016). Retrieved from http://www.etrend.sk/financie/ podnikatelia-mali-pravdu-daniaricasto-svoje-kontroly-natahuj.html

20. Vernarský, M. (2012). Limity daňovej kontroly. Justičná revue, 64(1).

17 The explanatory memorandum to the government bill which amends Act No. 222/2004 Coll. on Value Added Tax and which amends Act No. 331/2011 Coll., which amends Act No. 563/2009 Coll. on Tax Administration (Tax Procedure Code) and on Amendments and Supplements to Certain Acts. 